\title{
THE OCTOBER MEETING IN HANOVER
}

The five hundred ninety-third meeting of the American Mathematical Society was held at Dartmouth College on Saturday, October 27,1962 . About 100 persons attended, including 87 members of the Society.

By invitation of the Committee to Select Hour Speakers for Eastern Sectional Meetings, Dr. M. F. Atiyah of Harvard University gave an address entitled Topology and linear algebra. Professor R. H. Fox presided and introduced the speaker.

There were sixteen contributed papers presented at two sessions under the chairmanship of Professors L. J. Snell and H. B. Curry.

Bethelem, Pennsylvania

Everett Pitcher Associate Secretary 